\title{
The International Association of Hydrogeologists at 30
}

\author{
by John B.W. Day
}

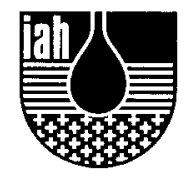

In the fourth in our series of profiles of IUGS affiliates, IAH Vice President Day describes the International Association of Hydrogeologists, established in 1956. IAH provides a world-wide focus for collaboration in research, study and management of water within the field of hydrogeology and related sciences. (Ed.)

\section{What is IAH?}

The Association's principal aim is to promote cooperation between scientists in all disciplines who are interested in hydrogeologic problems. It achieves this aim by conducting, promoting, and encouraging studies, and by cooperating with other organizations. IAH also sponsors meetings, and publishes scientific papers, commission reports and the proceedings of scientific conferences. The Association is a nonprofit association of individual members and is financed mainly by membership dues. National Committees serve on behalf of the members of a given country.

\section{Background and Structure}

The possibility of forming an international hydrogeological association was first discussed in London during the International Geological Congress (IGC) in 1948. At the next Congress, in Algiers, 1952, a provisional Committee was set up, but it was not until 1956 during the Mexico IGC that the Association was formally constituted. Affiliation to IUGS followed in 1964. By 1966, 111 members had paid their dues and this number had increased to 426 by the end of 1972 . At present there are over 1,800 members in 69 countries.

The current and past officers of IAH are listed in Table 1. The governing body of the Association is the Council, which consists of 11 elected members, including the officers. However, the Association's highest authority is the General Assembly of members, which is normally convened every four years during IGC meetings.

The Council meets at least annually and up to two to three times per year. Between meetings it delegates its authority to the Executive Committee, which consists of the President, Secretary-General and Treasurer. Advisors appointed by the Council and senior members who have held office, may assist the Council to reach its decisions. Close collaboration with the International Commission on Groundwater of the International Association of Hydrological Sciences (IAHS) is ensured by the inclusion of the Commission's President (currently H.J. Colenbrander, The Netherlands).

\section{Meetings}

The Council organizes and sponsors international meetings to study specific aspects of hydrogeology or related topics. It normally arranges with a national committee for an annual Congress, the proceedings of which are published and distributed to members. The Association may also support symposia jointly sponsored with other interested organizations such as IAHS.

Congresses and symposia take place anywhere in the world, and their detailed organization is the responsibility of hydrogeologists in the countries concerned. In recent years

\section{TABLE 1: COUNCIL OF IAH}

President:

M.R. Llamas, Universidad Autonona de Madrid, Dep. de Geologia, Cantoblanco, Madrid - 28049, Spain.

Past President: G. Castany, 3 Résidence du Petit Chambord, 92340 Bourg-la-Reine, france

Vice-Presidents: J.B.W. Day, Oakwoud, Dippenhall, Farnham, Surrey GUIO SEB, U.K.

J.E. Moore, Geoloqical Survey, Mail Stop 410, Reston, VA 22092, U.S.A.

G.S. Vartanyan, A.l-Union Research Inst. of Hydrogeol. \& Eng. Geol., Vsegeo, c/o P. Zeleny, 142452 Noginsky Raion, Moscorskaya Oblast., Moscow, U.S.S.R.

Secretary

General:

E. Romijn, Provincial Water Service, P.o. Box

rreasurer: 9090,6800 GX Arnhem, The Netherlands.

Members:

P.E. Groba, Warburghof 12, 3000 Hannover 61, F.R.G.

L.J. Anderson, Geological Survey of Denmark, 31 Thoravej, 2400 Copenhagen NV, Denmark.

J.J. Fried, Université Louis Pasteur, Inst. de Mécanique des Fluides, 2 rue Boussingault, 67083 Strasbourg, France.

A. Kohut, Ministry of Environment, 765 Broughton Street, Victoria, British Columbia, Canada vev $1 \times 5$.

R. Seokardi, Direktorat Geologitata Lingkungan, Jl. Diponegoro 57, Bandung, Indonesia.

H.J. Colenbrander, CHO-INO, P.O. Box 297, 2501 $\mathrm{BBD}, \mathrm{s}-\mathrm{Gravenhage,} \mathrm{The} \mathrm{Netherlands.}$

Advisors: $\quad$ S. Buchan, 14 Monks Road, Banstead, Surrey SM7 2EP, U.K.

A. Burger, Institut de Géologie de l'Université de Neuchatel, 11, rue Emile Argand, 2000 Neuchatel 7, Switzerland.

V.S. Kovalevsky, Water Problems Insitute, U.S.S.R. Acad. of Sciences, 13/3 SadovayaChemogryazskaya, 103064 Moscow 64, U.S.S.R. 
congresses have been held in Prague (Czechoslovakia), Vilnius (U.S.S.R.), Tueson and Huntsville (U.S.A.), Cambridge and Birmingham (U.K.), Montpellier (France) and Karlovy Vary (Czechoslovakia).

Future meetings are planned for Rome (20th Congress, April 12 th - 17th 1987, "Hydrogeology for Development") and Gueilin, China (21st Congress, September 1988, on a theme related to karst hydrogeology). There will also be various symposia within the framework of the 28 th IGC, to be held in Washington in July 1989.

\section{Commissions}

Commissions, Working Groups or Committees to study and to report on specific aspects of hydrogeology are a very important feature of IAH. The commissions, which may be short- or long-lived, operate under chairmen who appoint members in agreement with Council. There are now about ten commissions, and their reports when published are distributed to IAH members. Much of the work done by the Commissions contributes to the International Hydrological Programme (IHP), and specific aspects may be supported and even finaneed by Uneseo, the Food and Agricultural Organization, or other international agencies.

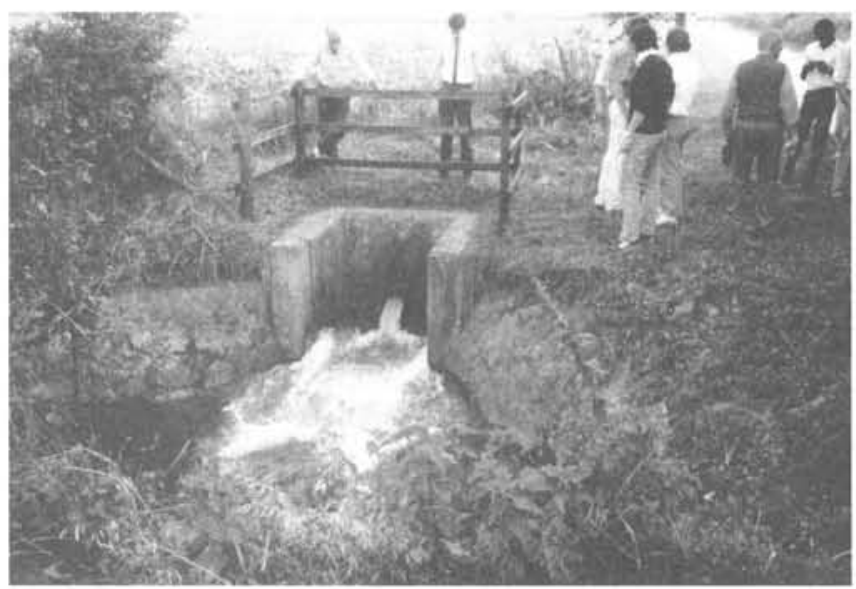

Figure 1: Participants on a 1985 IAH excursion to the Great Ouse Groundwater Scheme of northeastern England.

The earliest (and very productive) IAH commission, for the Hydrogeological Map of Europe, was set up under the chairmanship of the late Professor Herbert Karrenberg in 1960 to produce a grid of 30 sheets on a scale of $1: 1,500,000$. The Commission, continues to operate under the energetic chairmansip of W. Struckmeier (F.R.G.), and to date 21 map sheets have been completed, in conjunction with CGMW. These maps and notes have been printed in F.R.G. by the Bundesanstalt für Geowissenshaften und Rohstoffe (BGR), with some financial assistance from Unesco. However, the greatest costs of preparation have been borne by the various countries concerned. When complete, the Hydrogeological Map of Europe will not only constitute a major work, but will also provide at various seales national and regional maps that will set examples for other regions and countries to follow.

In August 1968 a Commission for Mineral and Thermal Waters (Chairman: vacant) was established, closely followed by the Commission for Karst Hydrogeology (H. Paloc, France). More recently, commissions have been established for Groundwater Protection (J. Vrba, Czechoslovakia), Hydrogeology of Voleanic Terrains (A. Aureli, Italy), Remote Sensing (M. Deutsch, U.S.A.). Hydrogeology of

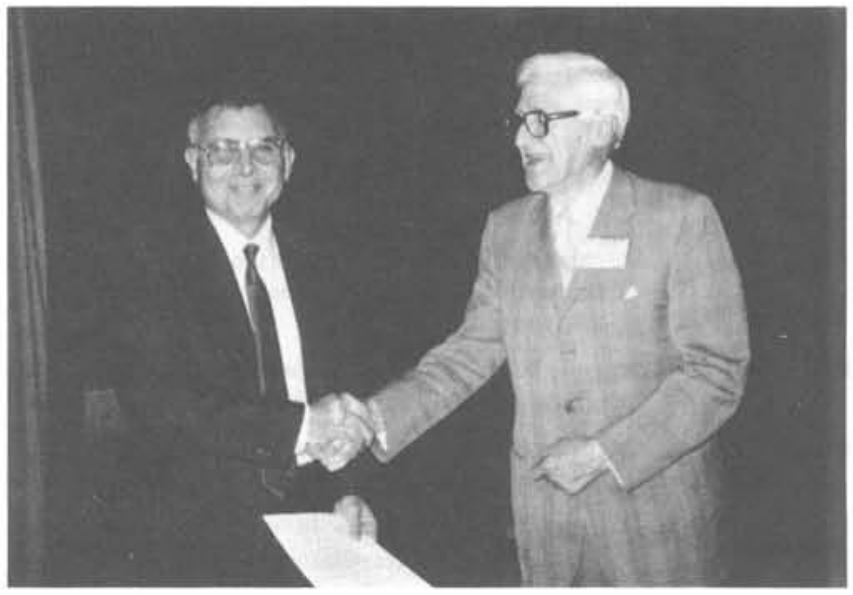

Figure 2: S. Buchan, President of the Association from 1972 to 1977, receiving an $I A H$ award from $M . R$. Llamas, current IAH President, Cambridge, 1985.

Mining Areas (R. Fernandez-Rubio, Spain), Hydrogeology of Coastal Areas (V. Cottechia, Italy), and Hydrogeology of Hazardous Wastes (P.E. LaMoreaux, U.S.A.). Under consideration is the formation of a Commission to investigate the particular problems of developing countries.

\section{National Groups and Their Roles}

For the promotion of regional and national activities, the association relies on the formation of national groups, which operate within the framework of the IAH Statutes and By-laws. These are administered by National Committees, which recruit new members, collect membership fees, publish newsletters and organize congresses and other meetings. A national group may consist of two or more members, but when the membership exceeds approximately 10, the groups elect or appoint a smaller number of representatives to form National Committees, with appropriate officers to conduct affairs on behalf of the group. All members of IAH are encouraged to form or to belong to such a National Group. Although the provisions of the IAH Statutes are binding upon all members, the Association has recently issued a series of advisory administrative Guidelines, for the conduct of National Groups and their committees as well as for commissions.

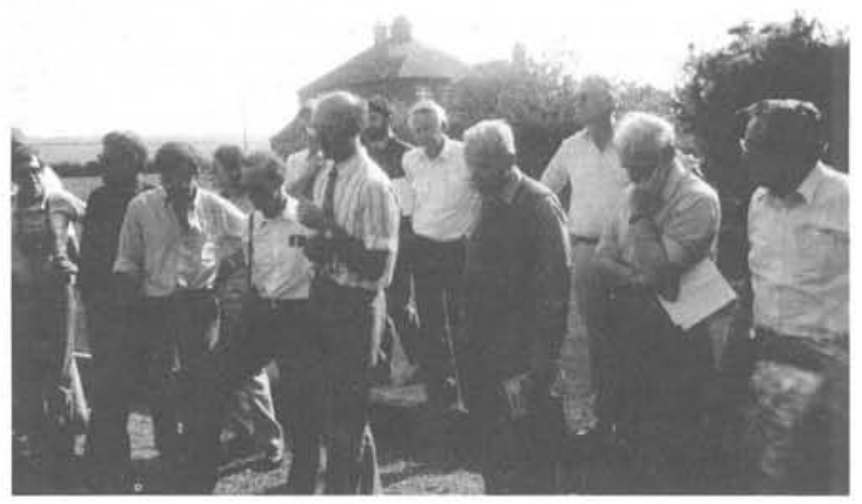

Figure 3: Reflecting on groundwater during an IAH excursion in England, 1985. 
ARGENTINA:

M.C. Fuschini Mejia, Comité Nacional para el Programa Hidrologico Interacional, Avda 9 de Julio 1925, 1332 - Buenos Aires, Argentina.

AUSTRALIA: W.H. Williamson, c/o Water Resources Commission, P.0. Box 952, North Sidney, N.S.W. 2060 Australia.

BELGIUM: A. Monjoie, Université de Liège, Laboratoíre de Géologie Générale, 7 Place du XX AoOt, 4000 Liège, Belgium.

BRAZIL: A. da Cunha Reboucas, Inst. Geosciencias USP, Univ. de Sao Paulo, AP 20899, Sao Paulo, Brazil.

CANADA: G. Gabert, 6th Floor Terrace Plaza, 4445 Calgary Trail South, Edmonton, Alberta T6H 5R7, Canada.

CZECHOSLOVAKIA: J. Vrba, Stavebni geologie n.p., Gorkého namesti 7, 11309 Praha 1, Czechoslovakia.

F.R. GERMANY: G. Goldberg, BGR, Postfach 510153, 3000 Hannover S1, F.R.G.

FRANCE: G. Castany, 3 Résidence du Petit Chambord, 92340 Bourg-la-Reine, France.

GREECE: G. Kallergis, I.G.M.E., 70 Messoghion Str., Athens 608 , Greece.

INDIA: K.K. Prasad, Central Groundwater Board, Silpukhuri, Gauhati - 781003, Assam, India.

IRELAND: $\quad$ P. Bennet, Geological Survey of N. Ireland, 20 College Gardens, Belfast BT9 6BS, Northern Ireland.

ISRAEL:

A. Issar, Ben Gurion Univ, of the Negev, The Jacob Blaustein Inst. for Desert Research, Sede Boqer Campus, Israel.

ITALY:
JAPAN:

KOREA:

NETHERLANDS:

POLAND:

RUMANIA:

SPAIN:

SWITZERLAND:

TURKEY:

Dairesi, Baskani, DS1, Yücetepe, Ankara, Turkey.

UNITED KINGDOM: J.B.W. Day, Dakwood, Dippenha11, Farnham, Surrey GU10 SEB, U.K.

U.S.A.:

F.L. Doyle, U.S. Department of the Interior, office of the Secretary, Washington D.C. 20240, U.S.A.

U.S.S.R.:

Comité Nat. de Géol. de I'URSS, 7 Pyzhevsky, 109017 Moscow B 17, U.S.S.R.

YugosLaviA: M. Janjic, Rudarsko-geoloski fak., Tolstogeva 5, 11000 Beograd, Yugoslavia.

ZAIRE:

Toshio Murashita, Fujimicho 3-46-1, Tachikawa, Sueng il Choi, 476-30 Mangwon-Dong, Mapo Ku, Seoul 121, Republic of Korea.

Cramer, National Inst, of Public Health and A. Rozkowski, Geological Institute Upper Silesian Sosnow, Groundwater

A.T. Pricajan, Ministère de Mines, Pétrole et Gélogie, 35 Bul. Men- deleev 5, 7000 Bucuresti Rosas 23, 28002 Madrid, Spain.

8. Schindler, Sous Courtils Bossus, 2515 Prêles, Switzerland.

Kalala Muamba, P.0. Box 20597, Kinshasa 15, Zaire.

\section{Finances}

Finaneing an international organization with individual membership is not without difficulties, most of which fall to the Treasurer to resolve. As of 1 January 1987, the individual membership fee will be raised from 30 to 55 Deutschmarks. The days when the IAH officers could finance their own Association activities are past, and the considerable costs of their travel and subsistance increasingly have to be met from central funds. There now has to be a certain amount of paid secretarial assistance, although full-time salaried of ficials or secretaries are not envisaged.

The payment of fees by members in countries with convertible currencies is fairly straightforward, but members from soft-currency countries are encouraged to pay their fees by means of the widely accepted mechanism of Unesco coupons. They may also pay in national currency through their national groups or committees, which, by special permission of the Council, may make equivalent payment to the Association in kind, for example by printing publications or by organizing meetings.

IAH members receive at no cost the published Memoirs of each annual IAH Congress, which may be sold elsewhere for as much as $\$ 45$ U.S. Members also receive copies of all IAH Commission publications (now in the "International Contributions to Hydrogeology" series published by Verlag Heinz Heise (Hannover, F.R.G.) a biennial IAH Bulletin, periodic newsletters, and membership lists. Registration fees for members who attend $\mathrm{IAH}$-sponsored meetings are commonly reduced.

Comment

Today's membership owes much to the efforts of past presidents and other officers of IAH. Many distinguished hydrogeologists have given time and energy to the Associ- ation; the debt is gratefully acknowledged. However, one outstanding name comes to mind, that of the late Louis Dubertret, Secretary-General from the Association's formation until his death in 1979. To this fine man the Association owes a great deal in recognition of his services. His widow, Rita, was recently made one of the Association's first Honorary Members, and she continues to be a familiar and much-loved personality at many IAH meetings.

If you are a practising professional hydrogeologist, and are not yet a member of IAH, then you should consider joining this organization. There are now National Committees in about 25 countries (Table II). If you decide to join, please do so through your National Group, if possible. You may also write directly to the Secretary-General (see Table 1) who will send you the Application Form.

Dr. J.B.W. Day a current VicePresident of IAH recently retired as head of the water resources branch of the British Geological Survey. During a long and productive career he worked on many projects overseas, especially in the field of environmental hydrogeology. He now lives at Oakwood, Dippenhall, Farnham, Surrey GU10 $5 \mathrm{~EB}$, U.K.

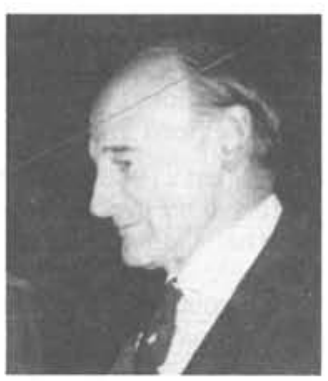

